\title{
Pengaruh Positioning terhadap Keputusan Pembelian Sepeda Motor Honda di Kota Langsa
}

\author{
Roni Mauliansyah \\ Fakultas Ekonomi, Universitas Samudra \\ e-mail: ronimauliansyah@unsam.ac.id
}

\begin{abstract}
Abstrak
Tujuan penelitian ini yaitu untuk mengetahui pengaruh positioning terhadap keputusan pembelian sepeda motor Honda di Kota Langsa. Jumlah sampel yang digunakan dalam penelitian ini berjumlah 96 responden. Metode analisis data yang digunakan yaitu analisis regresi linear sederhana, uji $t$ dan analisis koefisien determinasi. Dari analisis data diperoleh persamaan regresi linear sederhana yaitu $\mathbf{K P}=\mathbf{2 , 2 3 2}+\mathbf{0 , 5 0 5 P}$. Nilai konstanta yaitu 2,232 yang berarti jika positioning bernilai 0 maka keputusan pembelian adalah sebesar 2,232 satuan. Nilai koefisien regresi positioning mempunyai pengaruh positif yang berarti jika positioning meningkat sebesar satu satuan maka keputusan pembelian akan meningkat sebesar 0,505 satuan. Dari analisis koefisien determinasi diketahui bahwa positioning mempengaruhi keputusan pembelian sepeda motor Honda di Kota Langsa sebesar 35,0\% sementara sisanya 65,0\% dipengaruhi oleh variabel lain yang tidak diteliti dalam penelitian ini, seperti promosi dan harga. Positioning berpengaruh signifikan terhadap keputusan pembelian sepeda motor Honda di Kota Langsa yang dibuktikan dari hasil uji $t$ dimana diperoleh $t$ sig $0,000<0,05$ sehingga hipotesis diterima.
\end{abstract}

Kata Kunci: Positioning, dan Keputusan Pembelian

\section{PENDAHULUAN}

Suatu perusahaan beroperasi di samping untuk mendapatkan laba atau keuntungan juga untuk mempertahankan kelangsungan hidup bisnisnya. Dalam persaingan bisnis yang semakin ketat dewasa ini, kemampuan perusahaan dituntut untuk lebih cermat dalam persaingan bisnis. Jika perusahaan ingin tetap eksis dalam persaingan, maka perusahaan harus memperhatikan salah satu fungsi pokoknya yaitu pemasaran. Dalam melaksanakan pemasaran yang baik, produsen harus mengetahui dahulu apa yang menjadi kebutuhan dan keinginan konsumen, sehingga produk yang ditawarkan akan sesuai dengan permintaan konsumen.

Konsumen dalam memilih suatu merek produk akan melalui tahap percobaan terlebih dahulu, pada tahap ini seringkali konsumen akan mencoba berbagai merek yang berbeda. Jika dirasakan bahwa merek tersebut cocok dan memenuhi apa yang diharapkan dari produk sejenis maka konsumen akan terus mencari merek tersebut. Dalam usaha memenangkan persaingan, perusahaan harus mempunyai strategi pemasaran untuk produknya.

Keputusan pembelian konsumen menjadi faktor yang penting dalam penentu eksistensi perusahaan. Keputusan membeli konsumen dipengaruhi oleh keterlibatan konsumen dan kepercayaan mereka. Semakin tinggi konsumen terlibat dalam upaya pencarian informasi produk, semakin besar dorongan konsumen untuk melakukan pembelian. Disisi lain, konsumen semakin selektif dalam melakukan pemilihan produk untuk dikonsumsi.

Positioning juga diartikan tentang bagaimana cara produk didefinisikan oleh konsumen pada atribut penting yang dimiliki, atau tempat di mana produk dibedakan dalam 
benak konsumen dibandingkan dengan produk pesaing. Positioning yang dibutuhkan suatu produk adalah apabila produk mampu memenuhi keinginan dan kebutuhan konsumen, dengan cara membuat dan mengembangkan produk yang sesuai dengan selera konsumen, mutu dan kualitas yang terjamin, sehingga konsumen dapat dengan mudah memperoleh produk-produk tersebut.

Salah satu industri yang sedang berkembang pesat saat ini adalah industri sepeda motor. Dengan banyaknya perusahaan otomotif yang ada di Indonesia, maka konsumen akan lebih selektif dalam menentukan merek sepeda motor yang digunakan sebagai alat transportasi. Saat ini produsen sepeda motor asal Jepang tetap menjadi pilihan utama bagi masyarakat Indonesia karena berbagai macam keunggulan yang dimilikinya. Keputusan konsumen dalam menentukan atau memilih merek sepeda motor tertentu bukanlah hal yang begitu saja terjadi.

Honda sebagai perusahaan otomotif besar saat ini telah menyadari persaingan saat ini. Honda senantiasa memberikan keyakinan dan harapan kepada para pelanggannya untuk terus memberikan kepuasan kepada mereka. Sehubungan dengan keberadaan konsumen dan beraneka ragam perilakunya maka perusahaan harus benar-benar tanggap untuk melakukan pengamatan terhadap apa yang menjadi keingingannya. Jadi pada dasarnya pengusaha mempunyai kewajiban untuk memenuhi dan memuaskan konsumen melalui produk yang ditawarkan. "One Heart” sebagai filosofi perusahaan dalam memberikan produk dan layanan terbaik kepada masyarakat, baik untuk konsumen dan juga kepada publik.

Kota Langsa merupakan salah satu daerah yang pengguna sepeda motornya cukup banyak, salah satunya adalah merek Honda. Dari penelitian pendahuluan terhadap 20 responden yang menggunakan sepeda motor Honda di Kota Langsa, 7 diantaranya memberikan pendapat positif tentang positioning motor Honda yaitu dalam hal keunikan serta kualitas yang baik dengan harga terjangkau, namun 13 orang lainnya berpendapat bahwa positioning sepeda motor Honda belum begitu tepat. Mereka menganggap bahwa desain yang belum terlihat sporty pada motor Honda jenis matic dan jenis bebek, kualitas yang belum begitu sesuai dengan harapan seperti kestabilan motor saat dikendari dengan kecepatan tinggi khususnya pada motor Honda jenis bebek. Pada jenis motor sport, tampilannya kurang elegan dibandingkan kompetitornya yang selalu menciptakan inovasi dari desain, kapasitas mesin, serta kualitasnya secara keseluruhan.

Tujuan penelitian ini yaitu untuk mengetahui pengaruh positioning terhadap keputusan pembelian sepeda motor Honda di Kota Langsa.

\section{Pengertian Positioning}

Menurut Hasan (2008), positioning adalah penempatan sebuah merek di bagian pasar di mana merek tersebut akan mendapatkan sambutan positif dibandingkan dengan produk-produk saingannya. Menurut Kolter dan Armstrong (2008), penempatan atau positioning adalah tindakan merancang produk, dan bauran pemasaran agar dapat tercipta kesan tertentu di ingatan konsumen.

Soegoto (2009) mengemukakan bahwa positioning adalah cara membangun citra atau identitas di benak konsumen untuk produk, merek, atau lembaga tertentu dengan membangun persepsi relatif suatu produk terhadap produk lain. Menurut Tjiptono (2015), positioning adalah strategi yang berusaha menciptakan diferensiasi yang unik dalam benk pelanggan sasaran, sehingga terbentuk citra (image) merek atau produk yang lebih superior dibandingkan merek produk pesaing. Sedangkan menurut Daryanto (2011), positioning (posisi produk) adalah cara produk ditetapkan oleh konsumen berdasarkan beberapa atribut penting (tempat yang diduduki produk dalam ingatan konsumen dalam hubungan dengan produk pesaing). Menurut Abdurrahman (2015), positioning adalah cara produk didiferenkan oleh konsumen berdasarkan atribut penting, 
tempat produk berada dalam pikiran konsumen dibandingkan dengan produk pesaing.

\section{Tujuan Positioning}

Menurut Hasan (2008) tujuan dilakukannya positioning adalah:

1. Unutk menempatkan atau memosisikan produk di pasar sehingga produk tersebut terpisah atau berbeda dengan merek-merek yang bersaing.

2. Untuk memosisikan produk sehingga dapat menyampaikan beberapa hal pokok kepada para pelanggan.

3. Untuk mencapai hal yang diharapkan:
a. Pemenuhan sejauh mungkin kebutuhan segmen-segmen pasar yang spesifik.
b. Meminimumkan atau membatasi kemungkinan terjadinya perubahan yang mendadak dalam penjualan.
c. Menciptakan keyakinan pelanggan terhadap merek-merek yang ditawarkan.

\section{Indikator Positioning}

Adapun dasar-dasar positioning menurut Kotler dan Amstrong (2008) adalah sebagai berikut:

1. Atribut dan manfaat

Strategi positioning ini adalah yang paling sering digunakan oleh berbagai perusahaan di dunia. Atribut manfaat yang paling sering digunakan adalah daya tahan, kehandalan, dan kenyamanan.

2. Kualitas dan harga

Strategi kualitas dan harga sering juga dikatakan sebagai high quality and high price to good value (kualitas tinggi dan harga tinggi untuk nilai yang bagus) yang dikaitkan sebagai harga yang beralasan.

3. Kegunaan dan pengguna

Positioning ini mempresentasikan bagaimana produk digunakan atau asosiasi merek dengan orang-orang yang menggunakannya.

4. Kompetitor

Referensi yang jelas dengan dengan kompetitor baik secara eksplisit maupun secara implisit dapat digunakan sebagai strategi positioning yang sangat efektif hal ini karena dapat memperlihatkan perbedaan yang menjadi keunggulan produk atau jasa yang ditawarkan dibandingkan dengan yang mampu ditawarkan oleh kompetitor.

5. Budaya konsumen global

Positioning berdasarkan budaya konsumen global adalah strategi positioning yang menjadikan produk atau jasa sebagai simbol dari bagian budaya global. Positioning ini merupakan positioning yang efektif untuk produk remaja global, elit perkotaan dan mereka yang menjadi bagian dari budaya komersial transnasional.

\section{Prosedur Positioning}

Prosedur untuk melakukan penempatan posisi yang tepat meliputi delapan langkah pokok yaitu (Hasan, 2008):

1. Menentukan produk/pasar relevan

Suatu produk umumnya dimaksudkan untuk memenuhi lebih dari satu keinginan atau kebutuhan.

2. Pendataan kebutuhan pelanggan

Untuk melakukan positioning dengan tepat, maka marketer perlu mendata semua kebutuhan dan keinginan yang mungkin dapat dipenuhi oleh semua produk.

3. Mengidentifikasi pesaing

Pesaing primer adalah pesaing-pesaing yang bersaing untuk memenuhi kebutuhan inti, sedangkan pesaing sekunder adalah pesaing-pesaing yang tak langsung, yakni mereka tidak langsung muncul di pikiran bilamana seseorang sedang berpikir mengenai keinginan atau kebutuhan konsumen.

4. Menentukan standar evaluasi

Menentukan cara dan standar yang digunakan konsumen dalam mengevaluasi pilihan untuk memenuhi kebutuhan mereka. Biasanya seseorang akan mengevaluasi berbagai alternatif pemecahan masalah yang dihadapinya dengan cara dan berdasarkan standarstandar tertentu. 


\section{Membuat perceptual map}

Mengtahui bagaimana persepsi konsumen terhadap posisi pesaing (dengan membuat perceptual map). Pemasar perlu mengidentifikasi posisi yang ditempati pesaing dengan menggunakan perceptual map yang didasarkan pada atribut produk, situasi pemakai, atau kelompok pemakai.

6. Mengidentifikasi kesenjangan posisi

Mengidentifikasi kesenjangan atau gap pada posisi yang ditempati, maka dapat ditentukan daerah-daerah atau aspek-aspek yang belum tergarap maupun yang telah digarap banyak pesaing.

7. Merencanakan dan melaksanakan strategi positioning

Setelah pasar sasaran ditentukan dan posisi yang dikehendaki ditetapkan, maka pemasar harus merancang program pemasaran yang dapat memastikan bahwa semua informasi mengenai produk atau merek yang disampaikan kepada pasar akan menciptakan persepsi yang diinginkan dalam benak konsumen.

8. Memantau posisi

Posisi aktual suatu produk atau merek perlu dipantau setiap saat guna melakukan penyesuaian terhadap setiap kemungkinan perubahan lingkungan.

\section{Faktor-faktor yang Mempengaruhi Positioning}

Menurut Hasan (2008), efektif tidaknya positioning itu akan sangat dipengaruhi oleh empat faktor, yaitu:

1. Target pasar: strategi positioning akan diawali dengan target pasar (mengestimasi respon pasar, merumuskan alternatif strategi), memperhitungkan persaingan, kinerja (penjualan, pangsa pasar, profit) serta tersedianya sumber daya.

2. Daur hidup produk: masing-masing tahapan memiliki kondisi berbeda, memerlukan strategi positioning pemasaran yang berbeda.

3. Strategi unit bisnis: strategi unit bisnis akan terikat dengan strategi unit bisnis.
Penjabaran pengembangan strategi akan berbeda dengan harvest.

4. Program pemasaran: persepsi dibentuk melalui program marketing mix, terutama program komunikasi pemasaran dan program perbedaan produk.

a. Produk: melalui keunikan atribut, jasa pengiring, merek, kemasan, dsb.

b. Distribusi: melalui keunikan jenis, intensitas dan pola saluran.

c. Harga: melalui metode, posisi relatif dan manajemen harga.

d. Promosi: melalui keunikan pesan, format, desain, strategi kreatif, saluran audiens, media, dsb.

\section{Pengertian Keputusan Pembelian}

Menurut Kotler dan Armstrong (2008), keputusan pembelian adalah adalah tahap proses keputusan dimana konsumen secara aktual melakukan pembelian produk. Menurut Tjiptono (2008), keputusan pembelian merupakan keputusan konsumen untuk membeli suatu produk setelah sebelumnya memikirkan tentang layak tidaknya membeli produk itu dengan mempertimbangkan informasi-informasi yang ia ketahui dengan realitas tentang produk itu setelah ia menyaksikannya.

Menurut Fahmi (2016), keputusan pembelian adalah tindakan konsumen dalam memutuskan sebuah produk yang dianggap menjadi solusi dari kebutuhan dan keinginan konsumen tersebut. Menurut Sutisna (2006), pengambilan keputusan oleh konsumen untuk melakukan pembelian suatu produk diawali oleh adanya kesadaran atas pemenuhan kebutuhan dan keinginan. Setelah konsumen menyadari kebutuhan dan keinginan tersebut maka konsumen akan melakukan tindak lanjut untuk memenuhi kebutuhan dan keinginan tersebut.

\section{Tahap-tahap dalam Keputusan Pembelian}

Sunyoto (2012) mengemukakan tahaptahap dalam pengambilan keputusan pembelian meliputi pengenalan masalah, pencarian informasi, evaluasi alternatif, 
keputusan pembelian, dan perilaku pasca pembelian.

1. Pengenalan masalah

Masalah timbul dari dalam diri konsumen yang berupa kebutuhan, yang digerakkan oleh rangsangan dari dalam diri pembeli atau dari luar. Berdasarkan pengalaman masa lalu, seseorang belajar bagaimana mengatasi dorongan ini ke arah satu jenis objek yang dapat menjenuhkannya. Semua rangsangan yang ada pada diri konsumen menyebabkan semua itu muncul dan bagaimana kebutuhan atau masalah ini menyebabkan seeseorang mencari produk tertentu.

2. Pencarian informasi

Setelah timbul suatu masalah berupa kebutuhan yang digerakkan oleh rangsangan dari luar, dan didorong untuk memenuhi kebutuhan tersebut, konsumen akan mencari informasi tentang objek yang bisa memuaskan keinginannya. Pencarian informasi tergantung oleh kuat lemahnya kebutuhan banyaknya informasi yang telah dimilikinya kemudian mengadakan penilaian terhadap infromasi yang diperolehnya.

3. Evaluasi alternatif

Dari informasi yang diperoleh konsumen, digunakan untuk memperoleh gambaran yang lebih jelas mengenai alternatifalternatif yang dihadapi serta daya tarik masing-masing alternatif. Untuk mengetahui proses evaluasi yang dilakukan konsumen terlebih dahulu harus dipahami beberapa konsep dasar yaitu: atribut golongan produk, keyakinan merek dagang, pembeli kemungkinan besar beranggapan bahwa kepuasan dapat diperoleh dari tiap produk berubah-ubah, dengan berubahnya tingkat alternatif dari tiap atribut, dan konsumen menentukan sikap terhadap merek melalui evaluasi.

4. Keputusan pembelian

Tahap evaluasi berakibat bahwa konsumen membentuk preferensi di antara alternatifalternatif merek dagang. Biasanya barang dengan merek yang disukainya adalah barang yang akan dibelinya. Di samping sikap, masih ada dua faktor yang mempengaruhi nilai seseorang untuk membeli yaitu: faktor sosial dan faktorfaktor situasi.

5. Perilaku pasca pembelian

Sesudah pembelian terhadap suatu produk konsumen akan mengalami beberapa tingkat kepuasan ataupun ketidakpuasan. Kepuasan sesudah pembelian, konsumen mendasarkan harapannya kepada informasi yang mereka terima tentang produk.

\section{Indikator Keputusan Pembelian}

Menurut Kotler dan Amstrong (2008), indikator-indikator keputusan pembelian yaitu sebagai berikut:

1. Keinginan untuk menggunakan produk Konsumen yang ingin menggunakan suatu produk biasanya akan mencari informasi mengenai produk yang akan dibelinya untuk mengetahui keunggulan-keunggulan yang ada pada produk tersebut.

2. Keinginan untuk membeli produk Setelah konsumen mengetahui keunggulan suatu produk maka ia mempunyai keinginan untuk membelinya.

3. Memberikan rekomendasi kepada orang lain

Konsumen yang telah menggunakan suatu produk biasanya akan merekomendasikan orang lain untuk menggunakan produk yang pernah dikonsumsinya.

4. Melakukan pembelian ulang

Jika konsumen merasa puas dengan produk yang dibelinya maka ia akan membeli kembali produk tersebut.

\section{Hubungan Positioning dengan Keputusan Pembelian}

Pembentukan positioning, konsumen dapat menciptakan persepsi terhadap produk atau perusahaan dan mencari berbagai informasi-informasi untuk proses keputusan pembelian. Perusahaan yang melakukan positioning akan menghasilkan posisi produk yaitu citra produk yang jelas, keunggulan yang relatif dibanding pesaing dibenak pelanggan. Sehingga positioning dapat diartikan persepsi yang pertama kali muncul 
ketika memikirkan suatu produk (Maylana, 2013).

\section{Hipotesis}

Rumusan hipotesis dalam penelitian ini yaitu positioning berpengaruh signifikan terhadap keputusan pembelian sepeda motor Honda di Kota Langsa.

\section{Jenis dan Sumber Data}

Adapun jenis data yang digunakan dalam penelitian ini yaitu:

1. Data kualitatif adalah data yang berupa karakteristik kategori atau ciri khas suatu objek penelitian (Sunyoto, 2012). Data kualitatif dalam penelitian berupa gambaran umum sepeda motor Honda dan teori-teori yang mendukung penelitian ini.

2. Data kuantitatif adalah data yang berupa angka-angka atau bilangan baik utuh maupun tidak utuh (Sunyoto, 2012). Data kuantitatif dalam penelitian ini berupa skor kuesioner yang telah diisi oleh responden.

Adapun sumber data yang digunakan dalam penelitian ini yaitu:

1. Data primer adalah data yang didapat dari sumber petama baik dari individu atau perseorangan (Umar, 2010). Data primer ini diperoleh melalui observasi, wawancara, dan pembagian kuesioner kepada responden.

2. Data sekunder merupakan data primer yang telah diolah lebih lanjut dan disajikan baik oleh pihak pengumpul data primer atau oleh pihak lain (Umar, 2010). Data sekunder dalam penelitian ini diperoleh dari artikel, jurnal, dan bukubuku yang ada kaitannya dengan penelitian ini.

\section{Metode Pengumpulan Data}

Metode pengumpulan data dalam penelitian ini yaitu:

1. Penelitian Lapangan, yang terbagi menjadi:

a. Observasi yaitu teknik pengumpulan data dengan pengamatan dari si peneliti baik secara langsung ataupun tidak langsung terhadap obyek penelitiannya (Umar, 2010). Observasi dalam penelitian ini dilakukan pada konsumen yang menggunakan sepeda motor Honda di Kota Langsa.

b. Wawancara adalah salah satu teknik pengumpulan data yang pelaksanannya dapat dilakukan secara langsung berhadapan dengan yang diwawancarai (Umar, 2010). Wawancara dalam penelitian ini dilakukan terhadap konsumen yang menggunakan sepeda motor Honda di Kota Langsa.

c. Angket (kuesioner) adalah suatu cara pengumpulan data dengan memberikan atau menyebarkan daftar pertanyaan kepada responden (Umar, 2010).

Skala pengukuran yang digunakan yaitu skala Likert dengan alternatif jawaban sebagai berikut:

Sangat Setuju (SS) diberi skor 5

Setuju (S) diberi skor 4

Kurang Setuju (KS) diberi skor 3

Tidak Setuju (TS) diberi skor 2

Sangat Tidak Setuju (STS) diberi skor 1

Kuesioner dalam penelitian ini diadopsi dari penelitian Mustain (2012).

2. Tinjauan Pustaka

Tinjauan pustaka atau survei literatur merupakan identifikasi, lokasi dan analisis dari dokumen yang berisi informasi yang berhubungan dengan permasalahan penelitian secara sistematis (Kuncoro, 2009). Penelitian kepustakaan dalam penelitian ini menggunakan bukubuku dan jurnal yang relevan dengan penelitian ini.

\section{Populasi dan Sampel}

Populasi dalam penelitian ini adalah konsumen yang menggunakan sepeda motor Honda di Kota Langsa.

Untuk menentukan jumlah sampel dalam penelitian ini digunakan rumus Paul Leedy sebagai berikut (Arikunto, 2013:179): 
$\mathrm{N}=\left(\begin{array}{c}\mathrm{Z} \\ - \\ \mathrm{e}\end{array}\right)^{2}(\mathrm{P})(1-\mathrm{P})$

Dimana:

$\mathrm{N}=$ ukuran sampel

$\mathrm{Z}=$ standard score nilai $\mathrm{Z}$ yang dipilih (nilai

$Z$ dengan $\alpha 10 \%=1,96)$

$\mathrm{e}=$ sampling error $(10 \%)$

$\mathrm{P}=$ proporsi harus dalam populasi $(5 \%)$

$\mathrm{N}=\left(\begin{array}{l}1,96 \\ - \\ 0,1\end{array}\right)^{2}(0,5)(1-0,5)$

$=96,04$ (dibulatkan menjadi 96)

Dengan demikian sampel yang digunakan dalam penelitian ini berjumlah 96 responden. Teknik sampling yang digunakan dalam penelitian ini adalah non probability sampling, yaitu teknik pengambilan sampel dengan tidak memberikan kesempatan yang sama bagi anggota populasi untuk menjadi sampel (Sugiyono, 2016). Teknik penentuan sampel dalam penelitian ini menggunakan accidental sampling, yaitu teknik pengambilan sampel secara kebetulan. Artinya, siapa saja anggota populasi yang secara kebetulan dijumpai saat dilakukan penelitian maka anggota populasi tersebut merupakan sampel dalam penelitian ini (Sugiyono, 2016).

\section{Metode Analisis Data}

Analisis regresi linier sederhana digunakan untuk mengukur pengaruh antara satu variabel bebas terhadap variabel terikat. Analisis regresi linier sederhana dapat dirumuskan sebagai berikut (Sugiyono, 2011):

$$
\mathrm{Y}=\mathrm{a}+\mathrm{bX}
$$

Keterangan:

$\mathrm{Y}=$ variabel terikat

$\mathrm{X}=$ variabel bebas

$\mathrm{a}=$ Konstanta

Persamaan regresi di atas dimodifikasi ke dalam persamaan berikut:

$$
\mathrm{KP}=\mathrm{a}+\mathrm{bP}
$$

Keterangan:

$\mathrm{KP}=$ keputusan pembelian

$\mathrm{P}=$ Positioning

a $=$ Konstanta

$\mathrm{b}=$ Koefisien regresi

Untuk menguji hipotesis, maka digunakan teknik analisis sebagai berikut:

1. Uji t

Digunakan untuk menguji apakah secara individu variabel bebas berpengaruh secara signifikan terhadap variabel terikat. Hipotesisnya yaitu:

a. $\mathrm{H}_{\mathrm{o}}: \mathrm{b}_{\mathrm{i}}=0$, positioning berpengaruh tidak signifikan terhadap keputusan pembelian

$\mathrm{H}_{\mathrm{a}}: \mathrm{b}_{\mathrm{i}} \neq 0$, positioning berpengaruh signifikan terhadap keputusan pembelian

b. Level of signifikansi yaitu: $5 \%$

c. Kriteria pengujian :

Jika nilai sig. $>\alpha=0,05$, maka hipotesis $\mathrm{H}_{\mathrm{o}}$ diterima dan $\mathrm{H}_{\mathrm{a}}$ ditolak

Jika nilai sig. $<\alpha=0,05$, maka hipotesis $\mathrm{H}_{\mathrm{o}}$ ditolak dan $\mathrm{H}_{\mathrm{a}}$ diterima

2. Koefisien Determinasi $\left(\mathrm{R}^{2}\right)$

Dalam analisis ini terdapat suatu angka yang disebut dengan koefisien determinasi atau yang sering disebut dengan koefisien penentu, karena besarnya adalah kuadrat dari koefisien korelasi $\left(\mathrm{R}^{2}\right)$, sehingga koefisien ini berguna untuk mengetahui besarnya positioning yang mempengaruhi keputusa pembelian.

\section{HASIL ANALISIS}

Pengaruh Positioning terhadap Keputusan Pembelian Sepeda Motor Honda di Kota Langsa

Pengaruh positioning terhadap keputusan pembelian dapat diketahui dari hasil analisi regresi sederhana.

Berdasarkan Tabel 1 dapat diketahui hasil persamaan regresi linear sederhana yaitu $\mathrm{KP}=\mathbf{2 , 2 3 2}+\mathbf{0 , 5 0 5} \mathrm{P}$.

Interpretasi dari persamaan tersebut adalah:

1. Berdasarkan persamaan regresi diketahui nilai konstanta yaitu 2,232 yang berarti 
jika positioning bernilai 0 maka keputusan pembelian adalah sebesar 2,232 satuan.

2. Nilai koefisien regresi positioning mempunyai pengaruh positif yang berarti jika positioning meningkat sebesar satu satuan maka keputusan pembelian akan meningkat sebesar 0,505 satuan.

Analisis selanjutnya adalah analisis koefisien determinasi $\left(\mathrm{R}^{2}\right)$ dengan hasil sebagai berikut:

Berdasarkan Tabel 1 diketahui nilai $\mathrm{R}$ square yaitu 0,350 atau apabila dipersentasekan sebesar $35,0 \%$. Artinya, positioning mempengaruhi keputusan pembelian sepeda motor Honda di Kota Langsa. sebesar 35,0\% sementara sisanya $65,0 \%$ dipengaruhi oleh variabel lain yang tidak diteliti dalam penelitian ini, seperti harga dan promosi.

\section{Pembuktian Hipotesis}

Pembuktian hipotesis dilakukan dengan menggunakan hasil analisis data dengan uji t atau uji secara parsial. Uji t bertujuan untuk mengetahui pengaruh secara signifikan dari variabel bebas terhadap variabel terikat. Pembuktian hipotesis dalam penelitian ini menggunakan uji $\mathrm{t}$ dengan membandingkan tingkat signifikansi dengan a $(0,05)$. Berdasarkan Tabel 1 dapat diketahui bahwa tingkat signifikansi (t sig) variabel positioning adalah 0,000 . Oleh karena t sig $0.000<0,05$ maka dapat dinyatakan bahwa variabel positioning berpengaruh signifikan terhadap keputusan pembelian sepeda motor Honda di Kota Langsa. Dengan demikian, hipotesis dalam penelitian ini diterima atau dapat dibuktikan kebenarannya.

Hasil penelitian menunjukkan positioning berpengaruh signifikan terhadap keputusan pembelian sepeda motor Honda di Kota Langsa. Hal ini dikarenakan konsumen merasa sepeda motor Honda memiliki keunikan baik itu dari sisi desain dan atribut lainnya yang tidak dimiliki oleh merek sepeda motor lain. Selanjutnya, kenyamanan dalam menggunakan sepeda motor Honda membuat konsumen tertarik untuk membeli kerena kenyamanan saat berkendara adalah yang utama bagi konsumen. Selain itu, konsumen juga merasa bahwa harga yang ditawarkan oleh Honda relatif terjangkau dengan banyaknya kelebihan dan keunikan yang ditawarkan sehingga konsumen memilih Honda dalam keputusan pembelian.

Hasil penelitian ini didukung oleh penelitian sebelumnya Pangestu (2016) yang menyatakan variabel positioning secara parsial berpengaruh signifikan terhadap keputusan pembelian produk herbal Nutrend. Selain itu, hasil penelitian ini juga didukung oleh penelitian Yuliana (2013) dimana berdasarkan hasil uji t diketahui bahwa secara parsial variabel positioning berpengaruh signifikan terhadap keputusan pembelian sepeda motor di Semarang.

\section{KESIMPULAN DAN SARAN Kesimpulan}

Dari analsis data dan pembahasan maka dapat ditarik keismpulan sebagai berikut:

Dari analisis data diperoleh persamaan regresi linear sederhana yaitu $\mathbf{K P}=\mathbf{2 , 2 3 2}+\mathbf{0 , 5 0 5 P}$.

1. Nilai konstanta yaitu 2,232 yang berarti jika positioning bernilai 0 maka keputusan pembelian adalah sebesar 2,232 satuan. Nilai koefisien regresi positioning mempunyai pengaruh positif yang berarti jika positioning meningkat sebesar satu satuan maka keputusan pembelian akan meningkat sebesar 0,505 satuan.

Tabel 1. Hasil Analisis Statistik

\begin{tabular}{|c|c|c|c|}
\hline Variabel & B & $\mathrm{T}$ & Sig. t \\
\hline Konstanta & 2,232 & 7,637 &, 000 \\
\hline Positioning &, 505 & 7,118 &, 000 \\
\hline R Square & ,350 & & \\
\hline
\end{tabular}

Sumber: Data Primer diolah, 2017 
2. Dari analisis koefisien determinasi diketahui bahwa positioning mempengaruhi keputusan pembelian sepeda motor Honda di Kota Langsa sebesar $35,0 \%$ sementara sisanya $65,0 \%$ dipengaruhi oleh variabel lain yang tidak diteliti dalam penelitian ini, seperti promosi dan harga.

3. Positioning berpengaruh signifikan terhadap keputusan pembelian sepeda motor Honda di Kota Langsayang dibuktikan dari hasil uji t dimana diperoleh t sig $0,000<0,05$.

\section{Saran} yaitu:

Adapun saran dalam penelitian ini

1. Perusahaan Honda sebaiknya lebih meningkatkan positioning yang mudah melekat di benak konsumen dengan menciptakan inovasi produk sepeda motor dengan body yang memiliki ciri khas sehingga dapat menjadi pembanding dan pembeda antara sepeda motor Honda dengan merek sepeda motor lainnya.

2. Sesuai dengan jargon Honda "One Heart", sebaiknya pihak Honda bisalebih baik dalam menyampaikan maksud jargon tersebut baik itu melalui penyampaian pesan-pesan khusus pada produk Honda sehingga positioning Honda lebih berhasil dan merek Honda lebih melekat dibenak konsumen.

3. Untuk peneliti selanjutnya hendaknya variabel yang diidentifikasi tidak terbatas pada positioning saja karena terdapat variabel lain yang berpengaruh terhadap keputusan pembelian sepeda motor Honda di Kota Langsa.

\section{DAFTAR PUSTAKA}

Abdurrahman, Nana Herdiana. 2015. Manajemen Strategi Pemasaran. Bandung: Pustaka Setia.

Arikunto, Suharsimi. 2013. Prosedur Penelitian: Suatu Pendekatan

Praktik. Jakarta: Rineka Cipta.

Daryanto. 2011. Manajemen Pemasaran.

Bandung: Sarana Tutorial Nurani
Sejahtera.

Fahmi, Irham. 2016. Perilaku Konsumen: Teori dan Aplikasi. Bandung: Alfabeta.

Hasan, Ali. 2008. Manajemen Pemasaran dan Marketing. Bandung: Alfabeta.

Kotler, Philip dan Amstrong, Gary. 2008. Prinsip-prinsip Pemasaran. Jakarta: Erlangga.

Kuncoro, Mudrajad. 2009. Metode Riset Untuk Bisnis dan Ekonomi. Jakarta, Erlangga.

Mustain, Hasma Laely. 2012. Analisis Pengaruh Strategi Positioning terhadap Keputusan Pembelian pada Konsumen Starbucks Coffee di Makassar. Skripsi. Fakultas Ekonomi dan Bisnis, Universitas Hasanuddin. Makassar.

Pangestu, Jessica, AA. 2016. Analisis Pengaruh Strategi Positioning terhadap Keputusan Pembelian Produk Herbal Nutrend. Jurnal Riset Bisnis dan Manajemen. Vol 4. No 2. Hal. 2012018.

Soegoto, Dedi. 2009. Manajemen Pemasaran. Bandung: Trisatya.

Sugiyono. 2016. Metode Penelitian Kombinasi (Mixed Methods). Bandung: Alfabeta.

Sunyoto, Danang. 2012. Konsep Dasar Riset Pemasaran \& Perilaku Konsumen. Yogyakarta: CAPS.

Sutisna. 2006. Perilaku Konsumen dan Komunikasi Pemasaran. Bandung: Rosdakarya.

Tjiptono, Fandy. 2008. Strategi Bisnis Pemasaran. Yogyakarta: Andi. 2015. Strategi Pemasaran. Yogyakarta: Andi.

Umar, Husein. 2010. Riset Pemasaran \& Perilaku Konsumen. Jakarta: Gramedia Pustaka Utama.

Yuliana, Rahmi. 2013. Analisis Strategi Pemasaran pada Produk Sepeda Motor Matik Berupa Segmentasi, Targeting, dan Positioning serta Pengaruhnya terhadap Keputusan Pembelian Konsumen di Semarang. Jurnal STIE Semarang. Vol 5. No 2. Hal. 79-9. 